„Bohemistyka” 2021, nr 1, ISSN 1642-9893

Jarmila VOJTOVÁ

DOI: $10.14746 /$ bo.2021.1.13

Masarykova univerzita

\title{
Vzpomínka na Stanislavu Kloferovou
}

Dne 13. července 2020 jsme se naposledy rozloučili s PhDr. Stanislavou Kloferovou, CSc., významnou českou lingvistkou, která od nás odešla předčasně ve věku nedožitých šedesáti pěti let 5 . července 2020 .

S. Kloferová se narodila 3. listopadu 1955 v Přerově a většinu života prožila v Brně. Po maturitě na gymnáziu se rozhodla studovat na brněnské filozofické fakultě. Dvouobor čeština-němčina absolvovala s vyznamenáním v roce 1979. V roce 1982 nastoupila do brněnského dialektologického oddělení Ústavu pro jazyk český ČSAV, kde pracovala 35 let (s výjimkou let 2000-2002, kdy pobývala na lektorátu na Vídeňské univerzitě). V letech 1993-2000 oddělení vedla.

V ÚJČ nejprve prošla vědeckou výchovou - v roce 1991 dosáhla vědecké hodnosti CSc. Ve své disertační práci podala obraz specifického vývoje jazyka na dosud neprobádaném a jazykově komplikovaném území v pohraničních nově dosídlených obcích v tehdejším Severomoravském kraji. Práce díky své materiálové spolehlivosti a metodologické kvalitě získala cenu Českého literárního fondu. Její přepracovaná verze byla vydána pod názvem Mluva v severomoravském pohraniči (Brno: Masarykova univerzita, 2000) a v mnohém není dodnes překonána.

S. Kloferová se badatelsky od počátku zaměřila na otázky české dialektologie. Dialektologii si doslova zamilovala, a tak se práce stala její celoživotní zálibou. Významný byl její podíl na všech důležitých projektech dialektologického pracoviště. Podílela se na př́pravných pracích $\mathrm{k}$ vydání Českého jazykového atlasu, zásadního díla české dialektologie. Byla členkou autorského kolektivu všech jeho šesti svazků (Praha: Academia, 1. díl 1992, 2. díl 1997, 3. díl 1999, 4 díl 2002, 5. díl 2005, Dodatky 2011; online: https://cja.ujc.cas.cz/e-cja), autorsky zpracovala celkem 100 mapových statí. Mimořádně přínosná a vysoce hodnocená je souborná kapitola Svazky izoglos v nářčcich (s 15 mapovými listy) v 5. dílu, jíž dr. Kloferová přispěla $\mathrm{k}$ hlubšímu pochopení a interpretaci územní diferenciace nářečí českého jazyka. Na základě materiálu představeného na 1500 mapách celého díla zde podala syntetizující jazykovězeměpisný pohled na areálové členění našich dialektů. Mapy izoglosových svazků přinesly nový, detailnější pohled na dialekty; mj. zde ukázala souvislost průběhu svazků izoglos s dějinami nositelů jazyka i některé př́íčiny vzniku jazykových hranic. Vedle svazků izoglos, které potvrzují dělení na tradiční nářeční makroareály, materiál představený na svodných mapách odkryl další zřetelné, doposud neznámé 
hranice. Reprezentace svazků izoglos v takovém rozsahu, v jakém ho podala v této studii S. Kloferová, nemá $\mathrm{v}$ nářečních atlasech slovanských národů obdoby.

Zásadní byl její podíl na koncepci a posléze i na zpracovávání a publikování hesel elektronicky realizovaného Slovníku náreči českého jazyka (dostupné z: http://sncj. ujc.cas.cz). Projekt vedla, o koncepci slovníku i postupu prací na něm informovala odbornou veřejnost průběžně, jmenujme např. studie Současná česká dialektologie po Českém jazykovém atlasu Slovník nářečí českého jazyka („Slavia” 82, 2013, 1-2, 169-174) nebo Ke koncepci celonárodniho nárečního slovníku (In: S. Myznikov (ed.), Slavjanskaja dialektnaja leksikografija 2, Sankt-Peterburg: Nestor-Istorija, 2016, s. 100-116).

Zapojila se rovněž do projektů Ústavu českého jazyka Filozofické fakulty Masarykovy univerzity, které vyústily ve vydání významných publikací Kapitoly z dějin české jazykovědné bohemistiky (J. Pleskalová, P. Karlík, R. Večerka, M. Krčmová (eds.), Praha: Academia, 2007; kapitola Dialektologie s. 336-376), Encyklopedický slovník češtiny (P. Karlík, M. Nekula, J. Pleskalová (eds.), Praha: Nakladatelství Lidové noviny, 2002) a jeho přepracovanou verzi Nový encyklopedický slovník češtiny (P. Karlík, M. Nekula, J. Pleskalová (eds.), Praha: Nakladatelství Lidové noviny, 2016 - autorka a spoluautorka 16 dialektologicky orientovaných hesel; online: http://www. czechency.org).

Poznání českého jazyka věnovala dr. Kloferová nemalou pozornost i mimo oblast dialektologie. Zajímaly ji zejména nářční jazykové kontakty česko-německé, problematika běžné mluvy i tematika onomastická. Studiu jazykových kontaktů přes hranice nářečí se věnovala průběžně od 90 . let 20 . stol. a úspěšně v něm zúročila i své znalosti germanistické, např. v článku $K$ německým výpůjčkám v nářečích („Slovo a slovesnost” 55, 1994, č. 3, s. 202-207) a v mnoha dalších. Mezioborový pohled a studium jazykových kontaktů uplatnila od roku 2005 rovněž při práci na Slovníku pomistnich jmen na Moravě a ve Slezsku, jehož hesla v elektronické podobě jsou od roku 2014 postupně zveřejňována na webových stránkách Ústavu pro jazyk český AV ČR (viz: http://spjms.ujc.cas.cz).

Účastnila se též mezinárodních projektů Česko-rakouské jazykové kontakty a Mluva vídeňských Čechů. Výsledky posledně zmíněného projektu byly publikovány v monografii U nás ve Vídni. Vídeňští Češi vzpomínaji (Brno: Masarykova univerzita, 1999; spolu s J. Balharem a J. Vojtovou); dr. Kloferová zde sledovala zejména mluvu nejmladší generace české menšiny ve Vídni, srov. též její články Jak dnes mluvi mladí vídeňští Češi I a II („Naše řeč” 81, 1998, s. 61-72, 169-178).

Poznatky a zkušenosti z odborné práce na kolektivních dílech ji inspirovaly $\mathrm{k}$ mnoha př́spěvkům, $\mathrm{v}$ nichž rozkrývala další pozoruhodné jazykové souvislosti, připomeňme např. studii Nad svazky izoglos v Českém jazykovém atlase („Naše řeč” 86 , 2005, č. 1, s. 5-18), dále stat’ o původu a významu jedné přezdívky Vy neznáte Cajzla?
(„Naše řeč” 89, 2006, s. 191-197) či článek o přenesených pojmenováních v nářečí Není svatba jako svatba („Linguistica Brunensia” 66, 2018, s. 41-48).

Studie o současné české dialektologii a areálové lingvistice publikovala také v zahraničí: v Rakousku, Německu, Polsku, Slovinsku, Bělorusku, USA, Velké Británii ad. Zmiňme především kapitolu Mapping the Slavic languages v publikaci International Handbook of linguistic Variation (A. Lameli, R. Kehrein, S. Rabanus (eds.), Berlin-New York: de Gruyter, 2010), v níž popsala inovativní využití jazykovězeměpisné metody v atlasech slovanských jazyků, nebo heslo o češtině (s pracovním názvem Czech) v The Oxford Guide to the Slavonic Languages (N. Bermel, J. Fellerer (eds.), Oxford University Press, v tisku), jež zpracovala spolu s M. Krčmovou a jehož vydání se již bohužel nedočkala

Vedle odborných statí psala se zaujetím články popularizační, které poutaly pozornost veřejnosti často už jen názvem (Slepá bábo, kam tě vedu; Kostka, kostkový olej a kostkové boty) a lehkostí, s níž byly formulovány. Sem se řadí její příspěvky v kolektivní publikaci Čeština nově od A do Ž (M. Pravdová, Praha: Academia, 2016) a dále kniha Život ve slovech, slova v životě. Procházka labyrintem českých nářeči (Praha: Nakladatelství Lidové noviny, 2018; jejíž editorkou byla spolu s M. Šipkovou), v níž se S. Kloferová podílela na úvodní stati, která zdařile uvádí čtenáře do problematiky nářečí a motivuje ho, aby v četbě pokračoval, a dále připravila 11 kapitol věnovaných nejen životu nářečních slov či frazémů, ale i tradičnímu způsobu života našich předků, s nímž jsou nářeční výrazy spojeny.

Bohatá bibliografie dr. Kloferové čitá bezmála 250 položek, jejichž témata ilustrují široké spektrum odborných zájmů autorky, které nelze v tomto příspěvku obsáhnout (úplnou bibliografii sestavila Stanislava Spinková a lze ji nalézt na stránkách časopisu „Linguistica Brunensia” 68, 2020, č. 2, s. 93-103).

Paralelně s vědeckým bádáním se $\mathrm{S}$. Kloferová věnovala pedagogické činnosti na brněnské filozofické fakultě. Od roku 1983 zde vedla jazykové kurzy na Letní škole slovanských studií. Na Ústavu českého jazyka Filozofické fakulty Masarykovy univerzity externě vyučovala od roku 1990. Vedla nejdřive semináře věnující se současné české morfologii a tvoření slov, od roku 2003 pak vyučovala výlučně dialektologii. Učila s nadšením a její semináře vzbuzovaly u studentů velký zájem. Ohlasy na její zasvěcenou a poutavou výuku potvrzují, že pouze skutečný odborník umí předat své poznatky mladé generaci a nadchnout ji pro svůj obor. Tento přirozený talent dr. Kloferová měla a vychovala tak řadu zájemců o dialektologii a o češtinu obecně, z nichž mnozí se češtinou dále odborně zabývají (mezi jinými i svou dceru, která dnes působí také v dialektologickém oddělení). Vedla mnoho diplomových prací, podílela se rovněž na doktorském vzdělávání, byla členkou oborové rady pro český jazyk. 
Na závěr nechme promluvit studenty, kteří u dr. Kloferové absolvovali dialektologické školení a kteří vždy o paní doktorce mluvili s nevšední sympatií a uznáním. Jejich slova by si jistě přál číst každý pedagog:

Poutavost a nadšení, s nimiž dokáže paní doktorka hovořit o dialektech, jsou úchvatné... Na paní doktorce je vidět že je na daný obor opravdu odbornice. Velmi se mi líbil její výklad, který

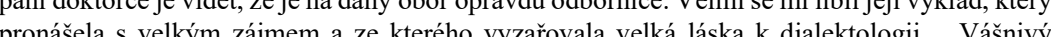
pronášla s velkýn zajmen a ze kténo vyzarovala velká láska $\mathrm{k}$ dialektologil... Văšnivý a poutavy výklad... Doktorka Klofer zajímavou a zábavnou formou.

Velká dáma české dialektologie - jak ji výstižně nazval Stefan M. Newerkla ve své vzpomínce - odešla od pracovního stolu plného nápadů a tvůrčích plánů. Je nesmírná škoda, že se její „,dobrodružství dialektologie“"l uzavřelo tak brzy a tak nešt’astně. Na Stanislavu Kloferovou budou vzpomínat její kolegové i početní žáci nejen jako na významnou lingvistku, odbornici na česká nářečí a výbornou vysokoškolskou učitelku, ale především jako na výjimečného člověka. Kdo měl štěstí s ní spolupracovat, ví, že byla moudrá a mimořádně laskavá, a nikdy na ni nezapomene. 